\title{
Best IASL Conference 2017 Paper: Preparing Teacher Librarians to Support STEM Education
}

\author{
Melissa P. Johnston, Ph.D. \\ University of West Georgia, USA
}

\begin{abstract}
A current focus in schools in the United States is STEM education, which prepares students for successful employment and post-secondary studies that require unique and more-technically advanced skills through teaching and learning in the areas of science, technology, engineering, and mathematics (STEM). This approach is grounded in problem solving, discovery, and exploratory learning, which requires students to actively engage in a situation in order to find its solution. Students engage in STEM learning in many different ways, with technology and digital resources playing an important role. The prominence of technology in STEM education provides leadership opportunities for teacher librarians. Yet, teacher librarians must be prepared to lead in the integration of technology to support STEM education. This report presents identified needs of teacher librarians in regards to supporting STEM education and discusses implications for better preparing pre-service teacher librarians to lead in order to address the needs of a new generation of learners.
\end{abstract}

\section{Keywords: STEM, Technology, Teacher Librarians, Leadership, Learning}

\section{INTRODUCTION AND RESEARCH PURPOSE}

STEM education prepares students for successful employment and post-secondary studies that require unique and more-technically advanced skills through teaching and learning in the areas of science, technology, engineering, and mathematics (STEM). STEM has been defined as an "interdisciplinary approach to learning where academic concepts are coupled with real-world lessons as students apply science, technology, engineering, and mathematics in contexts that make connections between school, community, work, and the global enterprise enabling the development of STEM literacy and with it the ability to compete in the new economy" (Tsupros, Kohler, \& Hallinen, 2009, p. 6). Educating students in the STEM areas not only prepares them for successful employment and post-secondary studies, but also for life, by teaching how to think critically and solve problems through a collaborative, hands-on, problem-solving, and project-based approach to education.

Despite the national initiatives focusing on STEM, students in the U.S. continue to rank lower in science, in general, and literacy in both math and science compared to their counterparts in other countries. American students rank $17^{\text {th }}$ out of 33 in science literacy and $25^{\text {th }}$ out of 33 in math literacy among students in developed countries according to the most recent Programme for International Student Assessment (PISA) report (Organisation for Economic Co-operation and Development, 2015), leading to continued concerns that U.S. schools are not preparing students to enter STEM fields (e.g., Desilver, 2017; Heim, 2016; National Academy of Engineering \& National Research Council, 2014; Randazzo, 2017).

STEM education is grounded in problem solving, discovery, and exploratory learning, which requires students to actively engage in a situation in order to find its solution (Young, 2013). Students engage in STEM learning in many different ways, with technology and media playing an important role, as students learn concepts most effectively when exposed to interactive resources like digital videos, audio and graphics, scientific data sets, virtual manipulatives, and simulations (e.g., Mardis, 2007; Mardis \& Payo, 2007; Perrault, 2007; Subramaniam, Ahn, Fleischmann, \& Druin, 2012; Subramaniam \& Edwards, 2014; Subramaniam et al., 2013; Young, 2013). Students need exposure to current and emerging technologies appropriate for STEM learning, but also instruction on how to interact with and 
utilize digital tools to "communicate, solve problems, and access, manage, integrate, evaluate, and create information to improve learning in all subject areas and to acquire lifelong knowledge and skills in the $21^{\text {st }}$ century" (American Association of School Librarians, 2009).

Teacher librarians with advanced digital information abilities, along with expertise in inquiry learning can engage students and support teachers by providing access to digital resources, encouraging students in authentic inquiry practices, and providing real-world collaborative learning opportunities to promote STEM learning. Therefore, the purpose of this research is to explore and document the needs of teacher librarians in regards to supporting STEM education efforts in their schools, specifically through the utilization and integration of digital tools and resources, to address the research question:

What are the knowledge, skills, and abilities needed by teacher librarians in order to support STEM learning?

This investigation specifically seeks to identify the current knowledge and abilities of teacher librarians in regards to supporting science, technology, engineering, and mathematics content areas and the gaps in knowledge and skills in order to serve as the basis for curriculum development for teacher librarians preparation programs, as well as creating professional development/continuing education opportunities for practicing teacher librarians.

\section{REVIEW OF THE LITERATURE}

Few studies to date have examined the topic of teacher librarians and STEM education; those that have, find that teacher librarians can play an important role in supporting students and teachers (Hoffman \& Mardis, 2008; Mardis, 2014; Rawson, Anderson, \& Huges-Hassel, 2014; Subramaniam et al., 2013; Subramaniam et al., 2012; Subramaniam \& Edwards, 2014). The American Association of School Librarians (AASL) defines five roles for teacher librarians, including that of information specialist, which has been found to demonstrate the most potential for supporting STEM education efforts (Hoffman \& Mardis, 2008; Mardis, 2007; Subramaniam et al., 2013; Subramaniam et al., 2012). As an information specialist, the teacher librarian is charged with "introduce[ing] and model[ing] emerging technologies, as well as strategies for finding, assessing, and using information," in order to ensure that learners are equipped with the skills and knowledge they need to succeed in the digital society of the $21^{\text {st }}$ century (AASL, 2009, p. 17). As information specialists, teacher librarians can serve as leaders in the integration of technology for STEM teaching and learning.

\section{The Role of the Teacher Librarian Supporting STEM}

Education research illustrates that utilizing technology effectively in the classroom can improve students' critical thinking skills, improve standardized test scores, provide numerous innovative educational opportunities, increase student motivation, and enhance the overall learning experience for students (e.g., Donovan, Green, \& Hartley, 2010; Fu, 2013; Johnson, Adams Becker, Estrada, \& Freeman, 2015; Levin \& Schrum, 2013; Delgado, Wardlow, McKnight, \& O’Malley, 2015). Yet, research finds that teachers continue to have difficulty locating appropriate digital content and are uncomfortable using digital content (Project Tomorrow, 2014, 2015).

Teacher librarians, as information specialist, can find resources to support STEM content areas for teachers to utilize in their instruction (Hoffman \& Mardis, 2008; McIlvain, 2010; Mardis, 2014; Perrault, 2007; Rawson, 2014; Subramaniam, 2015; Subramaniam et al., 2013). Digital resources and tools enrich student learning by enabling them to comprehend, visualize, and explain difficult concepts, which are otherwise difficult to portray inside the classroom, and by providing authentic learning and analytical experiences, such as demonstrations, simulations, experiments and observations of real world events, which were once limited to scientists. $[9,18]$ Digital video is one such resource that can be utilized to support learning and it is commonly the teacher librarian who recommends videos to teachers (Albertson \& Johnston, 2016; Mardis, 2007, 2014; McIlvain, 2010). The increased sense of urgency around how to effectively use digital tools and content to be able to impact student learning paired with teacher's continued struggles and discomfort with using digital content, positions teacher librarians to train and model for teachers how to effectively use technology and media for STEM learning (Johnston, 2012; Mardis, 2014; Pandora, 2009; Subramaniam et al., 2013). 
Teacher librarians can also interact with and engage all students in effectively utilizing digital resources, such as simulations, digital videos, and online gaming, that will develop scientific problem solving thinking (McIlvain, 2010; Perrault, 2010; Project Tomorrow, 2015; Subramaniam et al., 2013; Subramaniam et al., 2012). The top subject areas in which students use video to support learning are science and math (Henriques, 2016; Johnson et al., 2015). Teacher librarians can build a rich multimedia collection and teach students about utilizing a variety of digital tools, such as databases, online digital libraries, and apps, to locate information and to organize their findings through curriculum and interest based projects (Mardis, 2014; Mardis \& Payo, 2007; Subramaniam et al., 2013; Young, 2013). Teacher librarians can help teachers and students locate data from online databases to answer questions, collect evidence to support arguments, and develop data literacy practices especially related to science and engineering (Fontichiaro, 2016; Henriques, 2016).

Digital resources have opened up a participatory world where students can connect to a global world of information and learn; it is teacher librarians that can teach students ethical and responsible behaviors to become global literate citizens (Subramaniam et al., 2012). As Subramaniam et al. (2012) found, "school library program is the ideal place to connect young people, media, and technology to engage students in STEM" and by leveraging expertise in integrating, utilizing, and managing digital information, teacher librarians can engage students in K-12 libraries to facilitate inquiry and digital literacies in STEM areas (p. 163). "School libraries emerge as an ideal hybrid space to bridge the formal classroom with the broader world" by making connections between the digital resources and concepts and their application to the world outside of the classroom or library (Subramaniam et al., 2012, p. 163).

Yet, despite these opportunities for teacher librarians to become actively involved in STEM education, research suggests that teacher librarians are not embracing them Subramaniam et al, 2012; Subramaniam et al., 2013). Shultz-Jones and Ledbetter (2009) find that even though information literacy and science literacy goals correspond, collaboration does not often take place, attributing this to science and math teachers' concerns regarding the teacher librarian's credibility and a lack of awareness of how the teacher librarian can positively affect student achievement. The same holds true for math teachers, who discount the teacher librarians and the needed expertise in mathematics to serve as an instructional partner (Subramaniam \& Edwards, 2014). Another reported barrier is the teacher librarians themselves. Previous research finds that teacher librarians do not feel confident in their content knowledge of STEM areas (Mardis, 2007; Perrault, 2007; Rawson, 2014; Rawson, Anderson, Hughes-Hassel, 2015; Subramaniam et al., 2012; Subramaniam et al., 2013). Some attribute this to the fact that many teacher librarians come from a humanities background and lack the content knowledge in the STEM areas and are therefore hesitant to collaborate with teachers in these areas (Mardis, 2007; Perrault, 2007; Schultz-Jones, 2010; Shultz-Jones \& Ledbetter, 2009; Young, 2013). Additionally, teacher librarians state they have not been adequately prepared in school library preparation programs to support and collaborate in the STEM areas, and then in practice there is a lack of professional reading and professional development opportunities in these areas. This lack of familiarity with the STEM areas and content standards can also lead to an inadequate collection of resources - both print and nonprint to support STEM education (Hoffman \& Mardis, 2008; Schultz-Jones, 2010; Shultz-Jones \& Ledbetter, 2009; Young, 2013).

This deficit in the knowledge, skills, and abilities that teacher librarians need to support STEM has led to feelings of inadequacy with STEM content areas and digital tools, resulting in hesitation to work with students and teachers in these areas, therefore leading to leading to inadequate services for the STEM needs of students and teachers. A teacher librarian equipped with advanced digital information skills coupled with applied STEM capabilities can engage students and teachers by facilitating meaningful use of digital resources and providing real-world collaborative learning opportunities to promote and support STEM learning.

\section{RESEARCH DESIGN}

A needs assessment is a "systematic approach to studying the state of knowledge, ability, interest, or attitude of a defined audience or group involving a particular subject" (McCawley, 2009, p. 3) In this research the defined group is teacher librarians in rural areas of the southeastern U.S. and the topic is the 
state of their knowledge, ability, interest, or attitude in supporting STEM learning in their school library program. This type of assessment is conducted in order to allow the target audience to verify its own level of knowledge and skill, as well as its perceptions on the gaps and possible solutions (McCawley, 2009). This research followed the needs assessment process as defined by McCawley (2009): determine objectives, define the target audience, and collect the data; and utilized the methods of key informant interview and observation for data collection.

\section{Determining Objectives}

The first step in conducting a needs assessment is to determine the objectives of the study. The objectives of this study were taken from the overarching research question: 1) determine the knowledge, skills, and abilities that teacher librarians working in STEM schools felt were needed in order to support STEM education efforts; and 2) learn if teacher librarians perceived if they had been adequately prepared for this role; and if not, where do they perceive the gaps. It is important in a needs assessment to not limit information gathered to just existing knowledge or skills, but to investigate what the audience already knows or believes about the topic, what other efforts they may have taken to address deficiencies, and the audience's opinions and perceived solutions (McCawley, 2009).

\section{Defining the Target Audience}

Needs assessments research documents the current situation for a target audience, therefore, the second step in conducting a needs assessment is to thoroughly define the target audience, or those who should provide the data (McCawley, 2009). The target audience for this study is teacher librarians working in schools that are designated as a "STEM school." For the purposes of this research a STEM school is one that has been certified by their state department of education or local area ruling school body as a STEM school, or has some type of "official" designation as a STEM school, academy, or magnet school.

To further define the target audience, a geographical criterion was imposed, as the rural southeastern U.S. Rural school districts are behind and face challenges, particularly when compared to urban/suburban schools in the advancement of STEM. These challenges include tight budgets, inflexible curricula, lack of technology, struggles with recruiting and retaining great teachers in shortage areas like STEM, and a lack of professional development opportunities for teachers. Therefore, teacher librarians working in rural areas in the southeast U.S. were selected as the target audience. The rural and culturally diverse populations found in these areas comprise some of the lowest socioeconomic indices in the country, so there is a critical need for support in STEM areas that a teacher librarian can provide.

\section{Collecting the Data}

The next step in the needs assessment process is to gather appropriate and sufficient data that provides concrete evidence that can be used to determine which of the possible means-to-the-ends are most effective and efficient for achieving the desired results (Gilchrist \& Williams, 1999). It was determined that the most appropriate methods to employ for this research were key informant interviews and observation. The needs assessment process is not a linear one, it is iterative with loops, with what you learn from your observations informing what you ask in the interview, and what you learn in the interview leading you to see things differently in your observations (McCawley, 2009).

\section{Key Informant Interview}

Key informant interview is a qualitative research method in which the researcher conducts indepth interviews with a select group of individuals who are likely to provide needed information, ideas, and insights on the particular subject of study (Gilchrist \& Williams, 1999; Kaplan, 2013; Tremblay, 2003). In-depth interviews are conducted with a small number of key informants, usually 15-35, and focus on a topic that the interviewees have first-hand knowledge. The interview is usually conducted using an interview guide that list topics or issues to be covered during the interview rather than specific questions. The interviewer frames the actual questions during the course of the interview. This semistructured interview with a key informant should have an informal tone, like a conversation. The interviewer probes to elicit more information from the informant throughout the interview. The primary 
goal is to obtain qualitative description of perceptions or experiences, rather than measuring aspects of the experience (Gilchrist \& Williams, 1999; Kumar, 1989; Tremblay, 2003).

Key informants are individuals who meet specific selection of criteria based on their personal experiences and knowledge, in the case of this research the key informants were defined in the targeted group, as those teacher librarians currently working in schools designated as STEM schools in the rural southeastern United States. Key informants were purposively selected because they are knowledgeable and/or have experience with the topic under study, in this case the knowledge, skills, and abilities needed to support STEM learning, and can provide significant contributions to the inquiry (Kaplan, 2013; Kumar, 1989; Tremblay, 2003).

State Department of Education websites were searched and utilized to locate schools designated as "STEM schools." The researcher then conducted internet searches to find the websites of each school to determine location, then locate the school library page to first see if they had a teacher librarian (not all did), and to look at the programming going on in the library. In staying with the suggested size of 15-35 informants, the researcher selected 35 teacher librarians to email to see if they would be willing to be interviewed about their efforts to support STEM learning in their schools. Twenty-six teacher librarians responded positively and agreed to be interviewed.

It is important to establish a rapport with the key informants in order to obtain in-depth information about practices and perceptions (Kaplan, 2013; Kuamr, 1989; Tremblay, 2003. The researcher began this rapport with email communication with an informal tone and explaining the project. The researcher traveled to each school to conduct interviews over a three-month time period. An interview guide was utilized with interview topics to be covered during the interview rather than specific questions, the researcher asked questions according to the situation to "seek insights, ask follow-up questions, explore different points made during the course of conversation and identify distinctions in perspectives" (Kaplan, 2013, p. 1). All questions were asked informally in a conversational tone, usually while walking around the school library rather than a formally sit-down interview. More issues or topics were covered during the interview than identified in the interview guide, because as the key informants talked about their experiences or giving views and recommendations, the researcher asked more probing questions to seek more details and clarification. This type of interview provides flexibility to explore new ideas and issues that are relevant to the study's purpose (Kaplan, 2013; Kumar, 1989; Tremblay, 2003). After obtaining permission, all interviews were recorded with a digital audio recorder and the researcher also took extensive notes throughout the interview.

\section{Observation Method}

Observation was chosen as complimentary to the interviews with the key informant teacher librarians due to the important part that the environment and use of space in the school library plays in supporting STEM learning (Schultz-Jones, 2010; Schultz-Jones \& Ledbetter, 2009; Subramaniam et al., 2012; Young, 2013). The needs assessment process is iterative and informal direct observations led to more questions for the informants during the interview. Observation allowed for notes of how space was being used, the activities going on in the school library, the collection, and of special programming to support STEM. The researcher made detailed notes of the setting and activities taking place in the library and most informants gave detailed tours and descriptions of how their spaces were being used and special programming going on such as STEM centers, makerspaces, robotics tables, and Lego walls; all these descriptions were recorded. Photos were also taken of each school library and ways that STEM learning was supported. Observation is also used as a way to increase the validity of the study, as observations help the researcher have a better understanding of the context and phenomenon under study. The audio interviews were transcribed each night after the researcher conducted the interview. A file was created for each interview that included the audio recording, transcripts of the recording, observation notes, and photographs taken.

\section{ANALYSIS AND RESULTS}


Analysis in needs assessment research is about looking for trends and patterns (McCawley, 2009). Thematic analysis is a method for identifying, analyzing, and reporting patterns (themes) within data. Themes that emerge "capture something important about the data in relation to the research questions" are important to the description of the phenomenon under study (Fereday \& Muir-Cochrane, 2006; Kaplan, 2013; Vaughn \& Clark, 2006). Therefore, thematic analysis of the interview transcripts, direct observation notes, and photographs was conducted. Since this is exploratory research, an inductive approach was taken in that the themes emerge from the frequent, dominant, or significant themes inherent in data (Vaughn \& Clark, 2006).

The data collected from the interviews and notes was transcribed by the principal investigator, during this process the initial thoughts and ideas were noted down as this is considered an essential stage in analysis (Vaughn \& Clark, 2006). The transcribed data was then read and re-read several times and, in addition, the recordings were listened to several times to ensure the accuracy of the transcription. This process of "repeated reading" and the use of the recordings to listen to the data, results in data immersion and refers to the researcher's closeness with the data (Vaughn \& Clark, 2006). Then the interview transcripts, direct observation notes, and photographs were uploaded into NVivo and sorted into folders based on the site where they were gathered. Word frequency queries were run and all data sources and all data were coded by word. The researcher conducted analysis to identify and synthesize recurring themes emerging from the data based on prevalence, which was counted in terms of the number of occurrence across all of the data sources collected from all the sites and the core meanings evident in the data that were relevant to the research objectives. The visual representation features in NVivo were utilized to sort the coded data in to overarching themes and then each piece of coded data was examined to ensure that the theme captures the meaning and aspects of the coded data. Sub-nodes were made according to these themes to capture additional data specific to these themes as well.

\section{FINDINGS}

The thematic analysis process that was applied to the transcripts elicited patterns or themes that were evident in the data. These themes are viewed as essential in determining the needs of all the participants. The major overarching themes emerged as: Knowledge, Technology, Resources, and Space. This report will focus on the theme of Technology as it relates to the purpose of the research, to identify the knowledge, skills, and abilities needed by school librarians in order to support STEM learning.

\section{Technology}

Technology was the most frequently mentioned topic by participants when discussing how they support STEM education in their schools. Concepts that emerged as sub-themes as needs were determined as: the knowledge of how to effectively integrate technology to support STEM; the ability to stay up-todate on emerging technologies, and the skills to teach students how to access and utilize digital information.

\section{Knowledge on How to Effectively Integrate Technology for Teaching \& Learning in the STEM Areas}

While an important aspect of teacher librarians supporting STEM content areas is the purchasing of a variety of technology and digital resources, participants spoke more about how to integrate the resources into the teaching and learning process. Participants expressed that sometimes they felt they did not have enough knowledge on how to integrate the resources effectively in the STEM areas. "There is so much technology that can be utilized for supporting the STEM nowadays ranging from digital microscopes to virtual reality simulations, but you need a sound understanding of how to best use these resources for learning. I think this is an area I could have learned more about in library school." Other participants expressed this deficit in their preparation programs as well stating "I feel like there was a lot of 'look at all these great resources you can find online,' but not enough learning the principles of integrating them to support learning."

One area of STEM that was frequently mentioned by participants was computational thinking, an important foundational component of STEM education. Participants spoke of a lack of knowledge from 
their preparation programs in this area and how they had taken it upon themselves to learn. One participant expressed "I had no idea what computational thinking was, much less how to teach it." Nearly all participants mentioned teaching coding in some way or form to students in their schools. Knowing how to code requires computational thinking skills and an understanding of how to troubleshoot, problem solve, and think critically; when a young person learns to code they gain STEM skills (Braun \& Visser, 2017). "I decided to begin a coding club for students during lunchtime as a way I could support the STEM goals of my school. It wasn't easy because I first had to teach myself, but there are a ton of great resources out there." This finding overlaps with the Knowledge theme in that teacher librarians need some background knowledge of the STEM content areas and what STEM education in general entails in order to effectively integrate technology to support teaching and learning in these areas.

Participants also frequently spoke about the expectation that they train teachers on technology. One teacher librarian expressed that "my district continually purchases equipment and other resources, like ipads for each school. But they never provide any training." The role of professional developer is one that the teacher librarian can enact and therefore support teachers. All but two participants mentioned the importance of providing training for teachers on technology for use to support STEM. Many STEM concepts can be hard for students to grasp just by reading about them, but the effective integration of interactive technologies like digital videos, audio and graphics, scientific data sets, virtual manipulatives, and simulations can bring concepts alive (Mardis \& Payo, 2007; Subramaniam \& Edwards, 2014; Subramaniam et al., 2012; Subramaniam et al., 2013; Young, 2013). Yet teachers still struggle with integrating technology effectively for instruction. Participants expressed that there was the expectation from their administrators that they assist with this. "My principal sees that I should be more than just a provider of these great resources for teacher - that I should be able to train the teachers on how to use them too."

\section{The Ability to Stay Current on Emergent Technologies}

A common thread through the various responses of the participants was their implicit and explicit references to their concern to stay current on emerging technology. The interview responses demonstrate participants' beliefs that it is the responsibility of the teacher librarian to stay on the cutting edge of emerging technologies so they can introduce them to students and teachers. One participant expressed this saying that "it is like a full-time job just to stay up-to-date - it seems like every day there is some new digital resource." Another participant stated that while you are in your preparation programs it is easy to stay current with information from courses and from other classmates, yet "when I got out into practice I felt like I was falling behind - it was hard to keep up." Other teacher librarians shared ways that they do strive to stay current: reading journals, webpages/blogs, social media (Twitter was mentioned by every participant), going to conferences, and attending trainings. The participants also spoke of learning from other teacher librarians through informal channels, but also through professional organizations. This echoes previous research which found professional organizations as an enabler for teacher librarians acting as leaders in technology integration (Johnston, 2012).

\section{Skills to Teach Students About Digital Information}

School librarians are responsible for developing "information skills that will enable [students] to use technology as an important tool for learning" (AASL, 2009, p. 13). Technology has become a crucial element of teaching and learning, especially when it comes to preparing students that are equipped with the skills and knowledge they need to succeed in the technological society of the 21 st century and beyond.

Education research illustrates that utilizing technology effectively in the classroom can improve students' critical thinking skills, improve standardized test scores, provide numerous innovative educational opportunities, increase student motivation, and enhance the overall learning experience for students. In modeling and partnering with teachers, school librarians can guide instructional design and offer expertise on the integration of emergent technologies to create engaging and relevant learning experiences for students (AASL, 2009; Johnston, 2012). As information specialists and educators, teacher librarians can engage students and support teachers by providing access to and instruction for utilizing digital resources, encourage students in authentic inquiry practices, and provide real-world collaborative learning opportunities to promote STEM learning. Participants expressed their efforts to teach students 
through partnering with teachers. "I work with teachers whenever possible to develop inquiry based lessons that we can connect to science." Inquiry based learning was mentioned frequently by participants, which was expected since the Standards for the 21st Century Learner for K-12 school libraries in the United States are based on inquiry learning (AASL, 2009). There was a strong focus on teaching students how to locate and use information they find online, through databases and other online resources. "I have increased my subscriptions to online databases, especially those with a science focus, and I have expanded my teaching about the databases through all grade levels - even down to first grade." And in speaking about how they teach these skills, participants stated "I try to incorporate teaching databases into authentic research lessons and projects with each grade level." Teacher librarians need the skills to teach students about digital information - locating it, accessing it, evaluating it, and utilizing it.

\section{IMPLICATIONS}

The overall findings signify a need for teacher librarian preparation programs to adapt to better prepare students for the expectations of today's teacher librarians, especially for the role of information specialist. Teacher librarians need to be able to support technology integration efforts in all curricular areas, but especially STEM where technology and media play such an important part in the teaching and learning of these subjects. Professors in preparation programs must stay up-to-date with the field, national initiatives that impact the profession, and design coursework that reflects this in order to best prepare future teachers librarians to meet demands and expectations. Teachers continue to find locating appropriate resources to utilize for instruction challenging and still struggle with effective integration (Johnston, 2012; Project Tomorrow, 2014, 2015). Teacher librarians need coursework that instills leadership skills, but also that teaches effective integration of technology for teaching and learning. This type of coursework must include learning the skills necessary to teach students how to locate, access, evaluate, and utilizing digital information within an inquiry based learning framework.

Teacher librarian preparation programs must prepare students to go into practice with strategies on how to stay up-to-date on emerging technologies. Preparation programs can teach students how to connect with other teacher librarians in the field and create a group of supportive colleagues or a community of practice. Students can also be introduced to various professional organizations where they can meet other teacher librarians and experience professional growth opportunities through conferences, workshops, blogs, and journals. Introducing students to various ways to stay current, such as social media and how to develop strategies for effectively utilizing these various outlets should be a part of every teacher librarian preparation program. Yet, it is also important to teach students to move beyond just their own comfort zone of school librarianship to expand their learning from other areas, for example using social media to follow STEM educators for the most current technologies for use in these areas.

The prominence of technology in STEM education provides leadership opportunities for teacher librarians. Yet, teacher librarians need coursework that instills leadership skills and teaches effective integration of technology for teaching and learning. This type of coursework will help them better serve to support teachers in their STEM teaching efforts and in teaching students the skills they need to interact with and utilize digital Information.

\section{CONCLUSION}

This study, as previous research, finds that the information specialist role of the teacher librarian demonstrates the most potential for supporting STEM education (Hoffman \& MArdis, 2008; Mardis, 2007; Subramaniam et al., 2012; Subramaniam et al., 2013). As an information specialist, the teacher librarian is charged with "introduce[ing] and model[ing] emerging technologies, as well as strategies for finding, assessing, and using information," in order to ensure that learners are equipped with the skills and knowledge they need to succeed in the digital society of the $21^{\text {st }}$ century (AASL, 2009, p. 17). Yet, this study builds on the previous research to identify the specific needs of teacher librarians in fulfilling this information specialist role. Findings contribute to the exploratory purpose of this study to identify needs of teacher librarians in regards to supporting STEM education. Implications demonstrate the need for 
teacher librarian preparation programs to adapt in order to better prepare pre-service teacher librarians to lead through the integration of technology in STEM areas in order to address the needs of a new generation of learners.

\section{REFERENCES}

Albertson, D., \& Johnston, M. P. (2016). Individual differences of science teachers and interactive video retrieval. The Electronic Library, 34(1), $42-57$.

American Association of School Librarians. (2009). Empowering learners: Guidelines for school library programs. Chicago, IL: American Library Association.

Braun, L., \& Visser, M. (2017). Ready to code: Connecting youth to CS opportunities through libraries report. Chicago, IL: American Library Association. Retrieved from

http://www.ala.org/advocacy/ sites/ala.org.advocacy/files/content/pp/Ready_To_Code_ Report_FINAL.pdf

Delgado, A. J., Wardlow, L., McKnight, K., \& O’Malley, K. (2015). Educational technology: A review of the integration, resources, and effectiveness of technology in K-12 classrooms. Journal of Information Technology Education: Research, 14, 397-416. Retrieved from http://www.jite.org/documents/Vol14/JITEv14ResearchP397-416Delgado1829.pdf Desilver, D. (2017). U.S. students' academic achievement still lags that of their peers in many other countries. Pew Research Center. Retrieved from http://www.pewresearch.org/facttank/2017/02/15/u-s-students-internationally-math-science/

Donovan, L., Green, T., \& Hartley, K. (2010). An examination of one-to-one computing in the middle school: Does increased access bring about increased student engagement? Journal of Educational Computing Research, 42(4), 423-441.

Fereday, J., \& Muir-Cochrane, E. (2006). Demonstrating rigor using thematic analysis: A hybrid approach of inductive and deductive coding and theme development. International Journal of Qualitative Methods, 5(1), 80-92.

Fontichiaro, K. (2016). Why data literacy matters. Knowledge Quest, 44(5), 21-27.

$\mathrm{Fu}$, J. S. (2013). ICT in education: A critical literature review and its implications. International Journal of Education and Development Using ICT, 9(1), 112-125.

Gilchrist, V. A., Williams, R. L. (1999). Key informant interviews. In B. F. Crabtree and W. L. Miller (Eds.), Doing Qualitative Research (pp. 71-88). California: Sage.

Guzey, S. S., \& Roehrig, G. H. (2009). Teaching science with technology: Case studies of science teachers' development of technology, pedagogy, and content knowledge. Contemporary Issues in Technology and Teacher Education, 9(1), 25-45.

Henriques, L. (2016). Science teachers - In what ways have you partnered with your school librarian? Retrieved from http://www.classroomscience.org/science-teachers-in-what-ways-have-youpartnered-with-your-school-librarian Heim, J. (2016). On the world stage, U.S. students fall behind. Washington Post. Retrieved from https://www.washingtonpost.com/local/education/on-the-world-stage-us-students-fall-behind/2016/ Hew, K. F., \& Brush, T. (2007). Integrating technology into K-12 teaching and learning: Current knowledge gaps and recommendations for future research. Educational Technology and Development, 55(3), 223-252.

Hoffman, E. S., \& Mardis, M. A. (2008). The status of technology, science and mathematics in U.S. middle school media centers: A national survey. In Proceedings of the International Association of School Librarianship 37th Annual Conference, Chicago, IL.

Johnson, L., Adams Becker, S., Estrada V., \& Freemna, A. (2015). NMC horizon report: 2015 K-12 edition. Austin, TX: The New Media Consortium.

Johnston, M. P. (2012). School librarians as technology integration leaders: Enablers and barriers to leadership enactment. School Library Research, 15(1). Retrieved from www.ala.org/aasl/slr Kaplan, C. (2013). The key informant interview. The Research Review, 3(1). Retrieved from http://www.ctfalliance.org/research_savvypractitioner.htm\#select 
Kaufman, R., Rojas, A. M., \& Mayer, H. (1993). Needs assessment: A user's guide. New Jersey: Educational Technology Publications, Inc.

Kumar, K. (1989). Conducting key informant interviews in developing countries. Agency for International Development. Center for Development Information and Evaluation.

Washington, D.C: A.I.D. Retrieved from www.alnap.org/pool/files/conducting-key-informant-interviewskumar.pdf

Levin, B., \& Schrum, L. (2013). Using systems thinking to leverage technology for school improvement: Lessons learned from award-winning secondary schools/districts. Journal of Research on Technology in Education, 46(1), 29-51.

Mardis, M. A. (2007). School libraries and science achievement: A view from Michigan's middle schools. School Library Media Research, 10. Retrieved from www.ala.org/aasl/slr

Mardis, M. A. (2014). Ready for STEM? A leading commercial multimedia database as a source for media-rich science, technology, engineering, and mathematics assets K-12 library collections. Library Resources \& Technical Services, 58(4), 250-264. Retrieved from https://journals.ala.org/lrts/ Mardis, M. A., \& Payo, R. (2007). Making the school library sticky: Digital libraries build teacher-librarians' strategic implementation content knowledge in science. Teacher Librarian, 34(5), 814.

McCawley, P. F. (2009). Methods for conducting educational needs assessment: Guidelines for cooperative extension system professionals. Retrieved from http://www.cals.uidaho.edu/ edcomm/pdf/BUL/BUL0870.pdf

McIlvain, E. (2010). NSDL as a teacher empower point. Knowledge Quest, 39(2), 54-63. National Academy of Engineering and National Research Council. (2014). STEM integration in K-12 education: Status, prospects, and an agenda for research. Committee on Committee on STEM Integration. Washington, DC: National Academies Press.

The Organisation for Economic Co-operation and Development (OECD). (2015). Programme for International Student Assessment (PISA) results: USA. Retrieved from http://www.oecd.org/pisa/ Pandora, C. (2009). STEM - How libraries provide STEM information. Ohio Media Spectrum, 61(1). Perrault, A. M. (2007). An exploratory study of biology teachers' online information seeking practices. School Library Media Research, 10, 1- 26.

Perrault, A. M. (2010). Making science learning available and accessible to all learners: Leveraging digital library resources. Knowledge Quest, 39(2), 64-68.

Project Tomorrow. (2015). From print to pixel: The roles of videos, games, animations and simulations within K-12 education. Results from the 2015 Speak Up Survey. Retrieved from http://www.tomorrow.org/speakup/SU15AnnualReport.html

Project Tomorrow. (2014). The new digital playbook: Understanding the spectrum of students' activities and aspiration. Retrieved from http://www.tomorrow.org/speakup/ SU13DigitalLearningPlaybook_StudentReport.html

Randazzo, M. (2017). Students shouldn't live in STEM deserts. U.S. News and World Report. Retrieved from https://www.usnews.com/opinion/knowledge-bank/articles/2017-05-10/the-us-mustaddress-disparities-in-access-to-stem-education

Rawson, C., Anderson, J., \& Hughes-Hassel, S. (2015). Preparing pre-service school librarians for science-focused collaboration with pre-service elementary teachers: The design and Impact of a crossclass assignment. School Library Research, 18. Retrieved from http://www.ala.org/aasl/slr/ Schultz-Jones, B. (2010). School librarians, teachers and optimal STEM learning environments," Knowledge Quest, 39(2), 12-18.

Schultz-Jones, B. \& Ledbetter, C. E. (2009). Building relationships in the school social network: Science teachers and school library media specialists report key dimensions. School Libraries Worldwide, 15(2), 23-48.

Subramaniam, M., Ahn, J., Fleischmann, K. R., \& Druin, A. (2012). Reimagining the role of school libraries in STEM education: Creating hybrid spaces for exploration. Library Quarterly, 82(2), 161-182. 
Subramaniam, M., Ahn, J., Waugh, A., Taylor, N. G., Druin, A., Fleischmann, K. R., \& Walsh, G. (2013). The role of school librarians in enhancing science learning. Journal of Librarianship and Information Science, 47(1), 1-14.

Subramaniam, M., \& Edwards, A. R. (2014). The collaboration conundrum between school librarians and mathematics teachers," International Journal of Libraries and Information Services (LIBRI), 64(2), 185-209.

Tremblay, M. A. The key informant technique: A non-ethnographic application. In R. G. Burgess (Ed.), Field research: A sourcebook and field manual (pp. 151-163). New York, NY: Routledge.

Tsupros, N., Kohler, R., \& Hallinen, J. (2009). STEM education: A project to identify the missing components. Pennsylvania, PA: Carnegie Mellon.

USAID Center for Development Information and Education. (1996). Performance monitoring and evaluation tips: Conducting key informant interviews. 1996. Retrieved from http://dmeforpeace.org/sites/default/files/USAID_Performance\%20Monitoring\%20and\%2 0Evaluation\%20TIPS\%20conducting\%20Key\%20Informant\%20Interviews.pdf

Vaughn, V., \& Clarke, V. (2006). Using thematic analysis in psychology. Qualitative Research in Psychology, 3(2), 77-101.

Young, T. E. (2013). 24/7 STEMulation: Reinventing discovery. Library Media Connection, 31 (6), 20-22. 